\title{
"We look similar and have the same geographical origin": translocal encounters of second-generation Eritreans with a new generation of refugees from Eritrea
}

\author{
Samuel Graf ${ }^{1}$ and Susan Thieme ${ }^{2}$ \\ ${ }^{1}$ Department of Geography, University of Zurich, Winterthurerstr. 190, 8057 Zurich, Switzerland \\ ${ }^{2}$ Department of Earth Sciences, Free University Berlin, Malteserstr. 74-100, 12249 Berlin, Germany
}

Correspondence to: Samuel Graf (samuel.graf@geo.uzh.ch) and Susan Thieme (susan.thieme@fu-berlin.de)

Received: 10 March 2016 - Revised: 3 November 2016 - Accepted: 9 November 2016 - Published: 29 November 2016

\begin{abstract}
This article addresses the encounters of second-generation Eritreans with a new generation of refugees from Eritrea in Switzerland and identifies two main types of encounter: direct personal encounters and indirect in the public discourse. It suggests that the recently arrived Eritrean refugees present a new actor within the translocal social field with whom the second-generation Eritreans have to renegotiate their relation. We argue that these encounters frame the second-generation Eritreans' positionality within the translocal social field and influence their identity and their affiliation towards Eritrea and Eritreans. We find that encounters between second-generation Eritreans and new Eritrean arrivals are crucial moments through which second-generation Eritreans form their hybrid identity. Thus, the paper contributes to the debate on identity formation of the second generation by adopting a translocal perspective and provides insights into the diversity in the Eritrean diaspora in Switzerland.
\end{abstract}

\section{Introduction}

Eritrea has become one of the major source countries of refugees in the world today, for two main reasons: first, the postponement of demobilisation and the undetermined extension of national service, obligatory for all Eritrean women and men as a consequence of the implementation of the Warsay Yika'alo Development Campaign in 2002; second, the increasingly repressive measures of the authoritarian Eritrean government, starting with the imprisoning of members of the government demanding reforms and other critics (Bozzini, 2011a:72; Hepner and O'Kane, 2009:xxiv; Kibreab, 2013:2). However, escaping from Eritrea is not a completely new phenomenon. In the wake of the 30 -year struggle for independence (1961-1991), more than half a million Eritreans left their country for the countries neighbouring Eritrea, the Middle East, North America, and Europe (Glatthard, 2012:47; Hepner, 2008:176-177; Human Rights Watch, 2009:12).

Thus, there are two generations of Eritrean refugees, and they differ distinctively in their reasons for flight: the old generation that left the country due to the war for independence with Ethiopia, mainly in the 1970s and 1980s, with children born and/or raised abroad; and the new generation of Eritrean refugees, which has been fleeing from the current Eritrean regime since the early 2000s. The two groups have a controversial relationship, as they often link the generation of arrival to political attitudes towards Eritrea. There is a tendency for today's Eritrean refugees, the "generation asylum", to perceive those who migrated during the struggle for independence, the "generation nationalism", as loyal supporters of the Eritrean state, while the "generation nationalism" perceives the asylum seekers fleeing from the regime today as disloyal opponents of the regime (Hepner, 2015 [2009]:187188). However, Conrad shows that the generation of arrival cannot be straightforwardly equated with political attitudes towards the Eritrean state (see Conrad, 2006b:252), and the same is true for the second generation, as we have learned through our research. Thus, we label the two groups in this paper simply the old generation and the new generation of Eritrean refugees. 


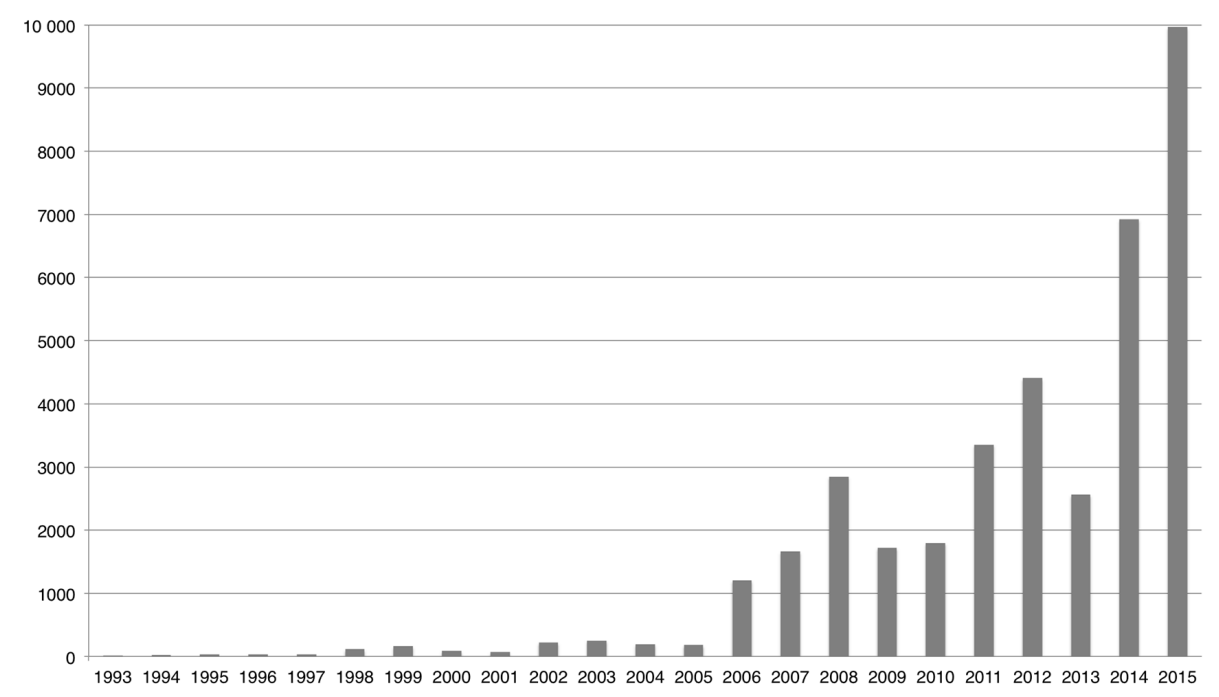

Figure 1. Numbers of Eritrean asylum applications in Switzerland (1993-2015). Data source: State Secretariat for Migration (2016).

Switzerland nowadays constitutes one of the major Western destinations for Eritreans (United Nations High Commissioner for Refugees, 2012:45). According to the honorary consul of Eritrea in Switzerland, only 1000 to 1200 Eritreans were resident in Switzerland in the 1980s (Interview 2014). However, the Eritrean diaspora in Switzerland has been growing since 2006 due to the arrival of new Eritrean asylum applicants (see Fig. 1). At that time, the legal situation for Eritrean applicants for asylum changed vastly as a result of a precedent which states that imminent punishment for refusing conscription or desertion from Eritrea is disproportionate and that therefore Eritreans with a well-founded fear of such a punishment are to be recognised as political refugees (Schweizerische Asylrekurskommission, 2006). As a consequence, the acceptance rate increased in 2006, and most Eritrean asylum seekers were granted asylum (Eyer and Schweizer, 2010:41). By the end of 2015, the Eritrean diaspora in Switzerland numbered more than 30000 people (State Secretariat for Migration, 2016; Swiss Federal Statistical Office, 2016).

This increase in numbers has led to a growing political and public debate about Eritrean asylum seekers in Switzerland. The public and media-driven discourse is largely characterised by the reproduction of stereotypes and prejudices (see Hepner, 2015 [2009]:188-189).

80 per cent of all Eritreans resident in the Canton of Zurich receive social welfare benefit. Their integration remains unsuccessful. (...) The access of the integration commissioners to the Eritrean community has remained difficult, and the authorities are regularly confronted with demanding attitudes and passiveness from the Eritreans (Ellner, 2014, own translation).
This quote exemplifies Swiss media reporting about the new arrivals from Eritrea. They are generally portrayed as a group struggling with social and economic integration, being highly dependent on social welfare, and bringing tensions, disunity, and sometimes even violent conflicts to the Eritrean diaspora (Scheurer, 2015; Schoop and Baumgartner, 2013; Serafini, 2013).

The purpose of this paper is to show how the new generation of Eritrean refugees in Switzerland influences the identity formation of those born and/or raised in the diaspora. Certainly, the identity of second-generation Eritreans consists of a range of aspects and is influenced by a number of factors. Looking at different moments of encounter more closely, this paper aims to reveal how the presence of new Eritrean refugees in Switzerland influences second-generation Eritreans regarding their Eritrean identity, their affiliation towards Eritrea, and their positioning in a changing translocal social field. Thus, it discusses one particular aspect of the identity formation of second-generation Eritreans. We will argue that the newly arrived Eritreans have created a new context that entails new negotiations of identity and affiliation to both Eritrea and the Eritrean diaspora for the secondgeneration Eritreans. We conclude that identity formation in a translocal context may involve various dynamic spaces of physical-personal and abstract encounters.

Thus, this paper contributes to the debate on the formation of identity in the second generation by focusing on socio-spatial interconnectedness and the experience of such through different encounters. With its focus on secondgeneration Eritreans, the paper addresses a subgroup of the Eritrean diaspora that has received relatively little attention and thus provides insights into the dynamics of and diversity among the Eritrean diaspora. 


\section{Methodology}

We gathered our data for this case study using two main methods. First, the first author of the paper carried out semistructured in-depth interviews with 19 second-generation Eritreans (10 women and 9 men) who were born and/or raised in the diaspora and are currently living in Switzerland. Interviews took place between October 2013 and July 2015 at different places in Switzerland, which we do not reveal to protect the privacy of participants. To select participants, we adopted a purposeful sampling strategy (Patton, 1990:169186) and defined certain criteria that participants had to meet: they had to be children of the first/old generation of Eritrean refugees, those who left Eritrea before 2000 due to the war of independence or the subsequent border war. Further, they had to have grown up and gone through central stages of their personal development outside Eritrea. Thus, participants are not necessarily born and/or raised in Switzerland, and the term "second generation", strictly speaking, is incorrect. Besides the term "second generation", Rumbaut (2004) introduced the terms " 1.75 ", "1.5", and " 1.25 " generation, which refer to children who arrived before the ages of 6 , between 6 and 12, and after 12 (Andall, 2002:391). According to Aparicio, individuals up to the 1.5 generation "underwent most of their primary socialisation in their host country" (Aparicio, 2007:1170). Thus, as all of the participants of this study, except one, may be allocated to the 1.75 generation, it appears justified to count these as second-generation Eritreans. The last criterion is that participants have to be residents in Switzerland today. All but one of the interviews were conducted in German and have been translated into English. All names of interviewees have been replaced by pseudonyms.

Second, additional data was collected through an expert interview with the honorary consul of Eritrea in Switzerland (2014), who has a long-standing relationship with Eritrea and the Eritrean diaspora in Switzerland. The expert interview proved fruitful for collecting in-depth insights about the Eritrean diaspora in Switzerland. Further, integrating the expert methodologically as a private person provided subjective patterns of explanation of the object of research. This enabled to reconstruction of whether explanations were offered from a professional or a personal viewpoint (see Bogner and Menz, 2009:46-53).

\section{Second generation, identity, and encounters in a translocal social field}

As much as translocality is seen as a phenomenon that can be described, it also refers to a particular condition, a particular way of being in the world, which is characterised by the tension and interplay of mobility and situatedness (Verne, 2012:19).

This paper brings together debates on translocality, second generation, identity formation, and encounters. Recent debates on translocality have examined the socio-spatial linkages and networks in the context of mobility and migration (Greiner and Sakdapolrak, 2013:373). Translocality studies emphasise the relational character between people and places both to recognise actors' relational and dynamic interconnection with specific locations and "to understand the (re)construction of places through the movements of people, material objects and ideas through places" (Verne, 2012:18). Applying the translocal approach enables the constitution of identity to be examined in the context of migration and mobility (Greiner and Sakdapolrak, 2013:378). Living in a translocal setting means that multi-local and/or mobile actors are connected to several different locations, with which they may identify and articulate their affiliation and "belongingness". Hence, places and localities play an important role in identity formation (see Oakes and Schein, 2006). In this context, the translocal perspective enables an examination of identity formation that transcends geographical boundaries by taking into account the complex nature of socio-spatial processes and interconnectedness. As the concept is concerned with "the local" it overcomes the so-called methodological nationalism dilemma (see Pries, 2005) by going beyond the spatial entity and primacy of the nation state and its national boundaries (Greiner and Sakdapolrak, 2013:373374; Oakes and Schein, 2006:xiii) and mapping out how other spaces and places can become significant during the process of international mobility (Brickell and Datta, 2011).

Members of a diaspora share a common origin. Whether really existing or imagined, this "home" is often equated with nation states (Hall, 1990:235). Nevertheless, the actual relationships transcend the connection to a nation state; they incorporate more complex interconnections to a range of places and therefore may be examined through the lens of translocality. In this light, a diaspora may be understood as a translocal community, a collective with a common origin situated and embedded in a translocal social field that spans a variety of multi-scaled spaces and locations (see Etzold, 2014:171-172). Such multi-local relations create shared interests and values amongst a group of people in the translocal social fields that manifest and maintain their common identity (Smith, 2001:184-185). The translocal community then presents the "result of a continuous process in the collective construction of identity, in which common origin functions as a medium" (Lohnert and Steinbrink, 2005:98). According to Bernal, Eritreans abroad, regardless their political affiliations to the Eritrean state, all refer to their common nation (Bernal, 2004:20). Thus, the Eritrean community can be considered a diaspora despite its internal tensions and divisions (Conrad, 2010:9-10).

Today, cross-border social fields and connections affect migrant communities more than ever, including their children, the second generation, in particular in "constructing, maintaining and negotiating collective identities" (Vertovec, 2001:575). Identities "are conceived as narratives, stories that people tell themselves and others about who they are, 
and who they are not, as well as who and how they would like to/should be" (Yuval-Davis, 2010:266). This includes two dimensions: an inclusive dimension, which defines social membership within particular groups, based on similarities and shared features, and an excluding dimension that stresses distinctions from others (Howard, 2000:369). Thus, identity formation is a continuous relational process of both internal self-description and external ascription of and by others. In addition to narratives, images, memories, desires, and physical encounters influence the formation of one's identity (Conradson and Mckay, 2007:167).

The concept of encountering is often employed in urban studies to explore living with difference or strangers (Valentine, 2008:324). By linking geographies of encounter with studies in psychology on prejudice (see Valentine and Sadgrove, 2014; Valentine, 2008), Valentine illustrates how encounter and stereotyping are intertwined and finds that "contact with difference" may both reduce and also solidify and even harden prevailing prejudices (Valentine, 2008:325). However, this case study shows how encountering not only affects the perception of "the others" but may further entail negotiation about oneself. For immigrants, the formation of a personal and a group identity "depends on constant interaction with the state, and the various institutions and groups in the country of immigration, as well as with the society of the country of origin" (Castles and Miller, 2003:39). Hence, immigrants' negotiation of their identity involves both encounters with new geographical locations and societies and the experience of oneself within the new setting (Ryan, 2007:419). Identity in a translocal context is thus constituted through relationships with and perceptions of mutual localities, influenced by (1) encountering physical and social spaces and places, (2) physical or personal encounters with various actors, and (3) encounters with perceptions, images, and narratives. However, since both translocal communities and their translocal social fields are dynamic social constructions created and recreated by their actors, identities in a translocal context constantly produce and reproduce themselves anew, exactly as Hall outlines the formation of diaspora identities (Hall, 1990:235).

This paper focuses on the identity of the second generation in a translocal sphere. Children of immigrant parents "weave their collective identities out of multiple affiliations and positionings and link their cross-cutting belongingness with complex attachments and multiple allegiances to issues, peoples, places, and traditions beyond the boundaries of their resident nation-states" (Çaglar, 2001:610). Thus, they face specific questions of how to relate to different people and places and negotiate, either consciously or unconsciously, their relationships towards different localities and societies and so position themselves within a translocal social field. Jiménez illustrates that the influx of new immigrants from the ancestral home thereby presents an important aspect for the identity formation of post-immigrant generations, which, however, has been only marginally discussed in research (see Jiménez, 2008). The new Eritrean refugees thus may be understood as influential translocal actors regarding identity formation of second-generation Eritreans. In summary, this framework enables an examination of how encounters with a new translocal actor, the new generation of Eritrean refugees, influence the dynamic process of identity formation of second-generation Eritreans regarding their Eritrean identity and their stance towards Eritrea and the Eritrean diaspora.

Various scholars have engaged with issues concerning the identity formation of second-generation Eritreans. The scholars focus on their relationship to the countries and societies of residence, discuss the formation and maintenance of Eritrean national identity amongst the second generation, and examine how members of the second generation relate to both the Eritrean state and Eritrean society (Arnone, 2010; Hepner, 2009b; von Nolting, 2002; Tecle, 2012; Zerat, 2009). Blood and kinship form the basis of their Eritrean identity, while knowledge of cultural aspects and features, most importantly language, are important means through which they perform it (Arnone, 2010:165). It is mainly parents and other community members who substantially influence the identity formation of second-generation Eritreans, since the second generation has only limited direct interactions with Eritrea (Zerat, 2009:67).

However, scholars have depicted that the Eritrean state may also play a vital role in this process. They refer to the Eritrean state as a "transnational state" (see Al-ali et al., 2001; Hepner, 2009a; Tecle and Goldring, 2013), because it actively targets its diaspora and promotes national identity. A prominent example of the state's translocal activities is the creation of the Young People's Front for Democracy and Justice (YPFDJ). This is the exiled youth branch of the Eritrean ruling political party, the People's Front for Democracy and Justice (PFDJ), and it promotes national identity and belonging specifically amongst those who were born and/or raised in the diaspora (Tecle, 2012:45). A second instance is the Know-Your-Country Tours (Zura nHagerka), visits organised by the state and offered to those born and/or raised abroad, with the objective of promoting national identity (see Conrad, 2006a, 2010).

This study investigates the effect of a recently emerged actor that may influence second-generation Eritreans' identity formation - the new generation of Eritrean refugees in Switzerland. This paper examines an additional and particular aspect of translocality: translocality that is brought in from outside by outsiders and takes place in the locality of people who are themselves more settled. New immigrants create "new frames of reference for identity" (Main and Sandoval, 2015:72) through interactions with the resident communities. Thus, the aim of this paper is to demonstrate how second-generation Eritreans encounter the new Eritrean refugees, and how experiences within this new translocal social field influence their affiliation to Eritrea and their translocal identities. 


\section{On encountering and grappling with the new generation of Eritrean refugees}

Interviews, discussions, and observations reveal that the arrival of the new generation of Eritrean refugees has shaped the translocal field and created a new context for the resident second-generation Eritreans that entails both direct and indirect examinations of questions about their Eritrean identity and about Eritreans and Eritrea in the broad sense. We identified two major types of encounter between secondgeneration Eritreans and newcomers through which the second generation starts to reflect about their identity, their affiliation and relationship to Eritrea and the Eritrean diaspora, and their own position within the translocal social field: directly through actual encounters with people from the new generation of Eritrean refugees and by encountering them indirectly as a collective through perceptions, narratives, and a growing public discourse about Eritrea, Eritreans, and Eritrean refugees in Switzerland.

\subsection{Encountering the new generation of Eritrean refugees}

When asked about childhood memories, many of the secondgeneration Eritreans recalled feeling that they were amongst the first Eritreans, indeed even the first Africans, in their new places of residence. Selam mentioned that at that time Swiss people would often have failed to identify them as Eritreans.

Today, Eritreans, I mean they are just... The train station is just full of them. But I have to admit, in the meantime their presence is so distinct and stark and there are so many Eritreans here by now, I feel neither startled nor enthusiastic or whatever. It's just like this. In the beginning, of course, it struck me as some kind of a joke. Because, you know, in former times, we [Eritreans] were all extremely exclusive. People did not know how Eritreans looked, and everybody just thought that we were Tamils. But now, they have grasped that the Horn of Africa exists, and people there look different from their picture of the "typical African" (Selam, interview 2014).

Most interviewees mentioned the absence of Eritreans in earlier times. Participants recounted that they had only little contact with other Eritreans, mostly limited to Eritrean families befriended by their parents. To meet each other, however, they sometimes had to undertake rather long journeys, sometimes even beyond the boundaries of their country of residence, attend community meetings, or go to cultural events and festivals. Similarly, Semhar pointed out how she looked out for Eritrean faces as a child and enjoyed going to a nearby asylum hostel to play with and meet other children from Eritrea. Thus, stories from their childhood showed that encounters were rather rare and mainly took place when people had deliberately decided to meet and were also willing to make a certain effort. However, second-generation Eritreans consciously discern that this has changed. In the same vein as Selam, interviews revealed that it seems to have become almost impossible to ignore the new arrivals in Switzerland. One interviewee commented that walking on the street today was like repeatedly seeing her mirror image or encountering herself. The physical appearance of the newly arrived Eritreans alone makes second-generation Eritreans realise that they look alike and evokes memories of their own or parental Eritrean origins and roots. Thus, the translocal social field has been changing, and the newly arrived Eritreans become new actors with which second-generation Eritreans' negotiate their Eritrean identity.

As a result of the rapidly growing numbers of Eritreans in Switzerland, encounters take place with increasing frequency throughout the public sphere, at bus and train stations, on public transport, or in shops. Further, more rarely they may encounter each other at Eritrean events, celebrations, and gatherings. However, such random encounters mostly do not involve greater personal interactions.

So when [Eritreans who have lived here for a while] see you they automatically say... Either they say "Hi" or they say "Are you from..." and then you say "Hi". Sometimes they engage in a conversation, sometimes not. Just you have to acknowledge and say "Hi". That's it (Yohanna, interview 2014).

However, interviews revealed that it is commonly the new arrivals that initiate contact. Zerai, for instance, mentioned this:

Once, I was going down the escalator at the train station and there was this Eritrean woman in front of me. She turned around and told me in Tigrinya [the most common of the Eritrean languages] that I should dress warmer as it could get cold in this country. You know, I was just wearing this light sweater. I answered her that I would be aware of that since I was born here. Immediately, she faced away and did not take any interest in me anymore (Zerai, interview 2013).

He then added another episode in which two newcomers were talking about him in Tigrinya without realising that he understood them. He was not sure if they did not recognise him as an Eritrean visually or just identified him as a secondgeneration Eritrean and therefore did not think that he would know Tigrinya well. However, many participants mentioned that the new Eritreans address them in Tigrinya when they greet them or ask for directions. Thus, the new arrivals from Eritrea normally recognise them as Eritreans on the basis of their looks, which again makes them aware of their physical similarities. Hence, a two-sided process occurs: the secondgeneration Eritreans recognise themselves as having or have ascribed to them by others certain "Eritrean attributes". 
Besides visual aspects that make second-generation Eritreans aware of their Eritrean identity, they experience other, more discreet, characteristics through physical encounters with the new arrivals. Yohanna said that encountering Eritreans made her feel less Eritrean, because she realised that in some respects she is not typical of Eritreans, such as not speaking Tigrinya or being a rather individualistic person. In her case, the increasing presence of the new generation of Eritrean refugees thus entails an increasing awareness of the lack of such characteristics. Selam also stated that the presence of the new generation made her aware that she was different:

What I realise is that there are not that many parallels between them and me, except that we look similar and have the same geographical origin. But that's it. But if you then look at, for example, formal and cultural education, mindset, interests or simply fashion and the way one dresses... I'm not saying one is right and the other one is wrong. But it's just completely different (Selam, interview 2014).

Meeting people with Eritrean characteristics may raise awareness not only of differences but also of similarities. Kisanet explained that encountering the new generation of Eritrean refugees called to mind her Eritrean identity, since she was familiar with the language and the culture. Thus, encountering Eritrean characteristics might involve both differentiation and connectedness, a rising awareness of one's origin, and so a sense of belonging. Like physical appearance, this seems to be a mutual process influenced by the newcomers' attitudes to the second-generation Eritreans too. For instance, Zerai interpreted the two encounters mentioned above as showing that the newcomers would normally identify him as Eritrean, but that he then, as a second-generation Eritrean, was not fully acknowledged as one of them. Further, he recounted that the surprised reaction of new Eritreans to his rather good Tigrinya again show that they do not expect him to speak Tigrinya and thereby indirectly deny him certain Eritrean characteristics. Thus, regardless of the effects, it becomes clear that encounters with Eritreans of the new refugee generation make second-generation Eritreans aware of Eritrean characteristics that they may share.

More personal encounters or intense contacts between second-generation Eritreans and the new generation of Eritrean refugees seem to be rather uncommon. Only a few interviewees mentioned personal contact with new arrivals. Zerai said that he has some contact with an Eritrean neighbour and has relatives or friends he knows from Eritrea amongst the newly arrived Eritreans. Still, several interviewees have jobs in which they are in regular personal contact with Eritreans of the new refugee generation. In this way, they get to know their personal stories, become involved in their asylum claims, and help them cope with their new surroundings. Ariam mentioned that she had learnt a lot about
Eritrea from the new Eritrean refugees, and Helen explained that she only began thinking about her Eritrean heritage since she had interacted regularly with Eritreans. Personal contacts clearly entail a more intense involvement with Eritrea and Eritrean characteristics, but they also make second-generation Eritreans aware of their differences. However, we were unable to identify any clear influence of such encounter on our interviewees' position towards Eritrea.

Consequently, the influx of immigrants from the ancestral home country entails that characteristics such as language and the look become important aspects of the identity formation of post-immigration generations (see Jiménez, 2008). Facing people who look similar makes second-generation Eritreans aware of their common geographical origin and Eritrean roots. Encountering Eritrean characteristics evokes engagement with their own Eritrean characteristics and brings to light the complex and ambiguous negotiations of their Eritrean identity and position.

\subsection{Encountering the new generation Eritrean refugees as a collective}

The increasing presence of Eritrean newcomers constitutes an emerging collective of "others" within the translocal social field with whom the second-generation Eritreans renegotiate their relations. Besides facing individuals, secondgeneration Eritreans also encounter the new generation of Eritrean refugees as a group that is presented and perceived in a particular way, a group about which certain narratives and images exist. In general, interviewees perceive that the two generations of Eritrean refugees differ from each other and construct a rather stereotypical picture of the new arrivals.

There are Eritreans who reject other Eritreans. This is mainly due to different political attitudes. You surely have seen the news... There were fights amongst Eritreans. We did not experience such things in the former times. We were always decent people, following faithfully our chosen path with patience. But today this is totally different. It's mainly due to the newcomers, I think (Interview with Dawit, interview 2014).

The older generation has difficulties with the newcomers. Because the new arrivals just come and see what the old ones have achieved and therefore scorn them. (...) Like "look at them, they have a nice flat but did they ever do anything for the community...? They just sit here and support the government". And then, on the other side, you have the old generation that sees the newcomers as a young generation that just parties and gets drunk all the time. What's more, they get their residence permits, for which the old generation had to work 10 times harder, in just a few months and even get 
money from social welfare. And this then leads to these frictions (Amanuel, interview 2014).

Similarly, Luwam takes the view that the newly arrived Eritreans are not as she used to know Eritreans from previous times. Eritreans of the old generation, she said, used to have a distinct communal spirit and always helped and supported one another. Today, however, mistrust has evolved amongst Eritreans in Switzerland. Winta and Fenan observe that the new arrivals' scepticism is mainly directed towards unknown Eritreans and in particular towards the first generation of Eritrean refugees. This is mainly due to the political tensions within the Eritrean diaspora (see Glatthard, 2012), which have sometimes even erupted into violence for instance at an Eritrean independence day celebration or an Eritrean concert in Switzerland (see Schoop and Baumgartner, 2013; Schweizer Radio und Fernsehen, 2012). This atmosphere contributes to a breakup of the "remarkable sense of unity within the Eritrean diaspora" (Al-ali et al., 2001:594). However, Luwam does not blame the new arrivals for this suspicious atmosphere but the Eritrean regime. She takes the view that mistrust is already in the new generation of Eritreans' minds due to the climate of surveillance they would have experienced in Eritrea, an issue also taken up by other research (see Bozzini, 2011a, b). Nevertheless, the friction between the two generations is not only due to the political attitude that the others are assumed to have but also their lifestyle and behaviour in Switzerland. Like Amanuel, interviewees often characterised the newcomers in contrast to their parents' generation as a group that attracts negative attention, as they hang around in public places, are largely unemployed, mostly depend on social welfare, and barely make any effort to integrate into the resident society.

My mom used to get about 500 Swiss francs from social welfare. This wasn't enough to live, that's why she simply had to find a job and therefore also had to learn the language. That is not to say that we should cut welfare payments, but... (Zerai, interview 2014)

Welfare... Many of them do not want to be supported by the public purse. They want to work. But they often are forced to take welfare payments, as they don't find work. It is like a vicious circle. Even if going to language courses, without work they won't be able to learn German and integrate (Fenan, interview 2014).

The second-generation Eritreans indicate possible explanations for the newcomers' behaviour, such as personal life stories and experiences or changing conditions for migrants to stay in Switzerland and to integrate in the society. Winta mentioned that it is more difficult for Eritrean refugees to find a job than it was for the old generation of Eritrean refugees due to increasing competition and higher requirements for language skills and certificates, which prevent newcomers from finding work. Another participant added that the new Eritrean arrivals might not be acquainted with local application procedures. Further, Kisanet stressed that newcomers might suffer from the psychological consequences of their flight across the Sahara desert and the Mediterranean and that this might hinder their social and economic integration.

Such attempts to explain the newcomers' attitude show how second-generation Eritreans start to grapple with Eritrean characteristics and behaviour and Eritrean-ness in general. They rethink their relation to Eritrea and Eritreans. By encountering the new Eritreans as a group, they start to think about their own Eritrean identity and about their similarities with and differences from the new Eritreans. They negotiate their ambiguous identity and their connectedness with and their alienation from their Eritrean heritage.

Of course it does not feel good when your colleagues at work [who have read about an affray between Eritreans in the news] ask you "Hey, tell us, were you there on Saturday when they [the Eritreans] beat each other up?" (...) They fight instead of holding together. This feels really strange to me. But these people do not just have an easy time here. They certainly didn't leave Eritrea and face all that risk just for fun. They did so because they did not see any other solution. And when I then see the tragedies in Lampedusa for instance... In such moments I feel Eritrean (Idris, interview 2014).

However, the interviews showed that second-generation Eritreans normally draw a clear line between the two generations of Eritrean refugees and distance themselves from the new arrivals by attaching certain attributes to each group. Alike Dawit or Idris, interviewees referred to topics in the news that tend to generalize, stereotype, and highlight issues like welfare dependency or the passivity of the newcomers. Thus, it appears that the second-generation Eritreans take up and repeat the rather prejudiced prevailing public discourse about Eritrean asylum seekers in Switzerland. Furthermore, shared experiences and stories about the two groups contribute to constructing an image of the distinctness of the "others" and lead second-generation Eritreans to dissociate themselves from the newcomers by stressing their difference. However, most interviewees added, as shown above, possible explanations for the newcomers' attitude. These reveal that second-generation Eritreans do not simply believe that the newcomers have new Eritrean characteristics but account for these differences by referring to concomitant circumstances. Thus, this distancing from the new arrivals seems to be a response of the contemporary negative image of Eritreans attached to the newcomers rather than a differentiation from them as Eritreans. 


\section{Conclusions}

In this article, we have discussed the formation of secondgeneration Eritreans' identity and affiliation in a changing translocal context in Switzerland. The paper contributes to the debate on the identity formation of the second generation by adopting a translocal perspective and focussing on socio-spatial interconnectedness. The paper further provides insights into the diversity among the Eritrean diaspora and reveals that the relations between the second-generation Eritreans and the newly arrived generation Eritreans cannot be understood without the political context and the history of Eritrea's diaspora. We have shown that the contemporary arrival of a new generation of Eritrean refugees not only shapes the translocal sphere but also that they present an important new factor in the process of identity formation of those who were born and/or raised in the diaspora (see Jiménez, 2008). We have argued that encounters and interactions with the newly arrived Eritreans both personally and as a group in a discourse thereby represent crucial elements in this process. Focussing on encounters between the new immigrants and the post-migrant generation this study adds new insights to wider debates on the identity formation of the second generation by demonstrating how the changing translocal field may affect deliberations and negotiations of one's position within this field.

Like migrants, descendants of immigrant parents find themselves living in translocal contexts in which crossborder social fields and multi-scaled connections to different places play an important role in the formation of affiliations and identity. Thus, the concept of translocality enables the examination of the socio-spatial linkages and networks in the context of mobility and migration that construct and maintain collective identities (Greiner and Sakdapolrak, 2013:373; Vertovec, 2001:575). Translocal actors continuously create and recreate their socio-spatial interconnectedness and thereby redefine their affiliation to localities and their identity.

The arrival of a new generation of Eritrean refugees and the growth of the diaspora in Switzerland has crucially shaped the predominant translocal social field. For the second-generation Eritreans, the newcomers present a new translocal actor or collective that influences deliberations about Eritrea and Eritreans and thus about their identity. In this, the encounter with the Eritrean newcomer is one central aspect. This research reveals that the second-generation Eritreans mainly encounter the newcomers in two ways: first as individuals and second as a group in a discourse. Interpersonal encounters cause the second-generation Eritreans to become aware of their Eritrean identity and at the same time visualises differentness from the new Eritrean arrivals that may result in an ambiguous negotiation of their relation to Eritrea and Eritreans. Further, encountering the new generation of Eritreans in a discourse entails that second-generation Eritreans tend to distance themselves from the new genera- tion of Eritrean refugees. However, this distancing is more from the generally negative image of Eritreans found in public discourse than from them as Eritreans.

Identity formation in general is a relational process influenced by narratives, images, memories, desires, and physical encounters (Conradson and Mckay, 2007:167). This case study shows that translocal identity formation may be understood as an ongoing relational process in which both physical and more abstract encounters present central factors that influence translocal actors in their engagement with their felt connectedness and identity. Hence, identity formation in a translocal context may involve various dynamic spaces of encounters that influence the relation to various locations and the renegotiation of identities. Although new immigrants thereby play an important role, their influence on the identity formation process of post-immigrant generations from the same origin has received only little attention and thus needs to be taken into account in research on identity formation of people with immigrant background (Jiménez, 2008:1562). The Eritrean diaspora in Switzerland is special due to the two distinct generations of immigration, their tense relationship, and different perception of Eritrean politics that exists among Eritreans. Further, witnessing an influx of a large amount of new immigrants, as presented in this paper, may affect the encounters and their effects on identity formation of the postimmigrant generation in a particular way. On a more general level, the case study shows the central importance of a detailed understanding of the manner of encounters with new immigrants, since they are a crucial aspect of the identity formation process of post-immigrant communities influencing the (re)construction of self and others. Further, it indicates that the perception of marked differences between the two groups may entail a more intense and challenging negotiation of identity that, however, needs to be investigated through further research.

\section{Data availability}

Data are not publicly accessible.

Edited by: B. Korf

Reviewed by: three anonymous referees

\section{References}

Al-ali, N., Black, R., and Koser, K.: The limits to "transnationalism": Bosnian and Eritrean refugees in Europe as emerging transnational communities, Ethnic Racial Stud., 24, 578-600, doi:10.1080/01419870120049798, 2001.

Andall, J.: Second-generation attitude? African-Italians in Milan, J. Ethn. Migr. Stud., 28, 389-407, doi:10.1080/13691830220146518, 2002.

Aparicio, R.: The Integration of the Second and 1.5 Generations of Moroccan, Dominican and Peruvian Origin in 
Madrid and Barcelona, J. Ethn. Migr. Stud., 33, 1169-1193, doi:10.1080/13691830701541713, 2007.

Arnone, A.: Being Eritrean in Milan: the constitution of identity, Ph.D. thesis, University of Sussex, England, 2010.

Bernal, V.: Eritrea Goes Global: Reflections on Nationalism in a Transnational Era, Cult. Anthropol., 19, 3-25, 2004.

Bogner, A. and Menz, W.: The Theory-Generating Expert Interview: Epistemological Interest, Forms of Knowledge, Interaction, in: Interviewing Experts, edited by: Bogner, A., Littig, B., and Menz, W., Palgrave Macmillan, Basingstoke, 43-80, 2009.

Bozzini, D.: En état de siège. Ethnographie: Ethnographie de la mobilisation nationale et de la surveillance en Érythrée, Ph.D. thesis, Université de Neuchâtel, Switzerland, 2011a.

Bozzini, D.: Low-tech Surveillance and the Despotic State in Eritrea, Surveill Soc., 9, 93-113, 2011b.

Brickell, K. and Datta, A.: Introduction: Translocal Geographies, in: Translocal Geographies: Spaces, Places, Connestions, edited by: Brickell, K. and Datta, A., Ashgate Publishing, Farnham, 3-20, 2011.

Çaglar, A. S.: Constraining metaphors and the transnationalisation of spaces in Berlin, J. Ethn. Migr. Stud., 27, 601-613, doi:10.1080/13691830120090403, 2001.

Castles, S. and Miller, M. J.: The Age of Migration: International Population Movements in the Modern World, 3rd ed., Guilford Press, New York, 2003.

Conrad, B.: "A culture of War and a Culture of Exile": Young Eritreans in Germany and their Relations to Eritrea, Revue européenne des migrations internationales [online], 22, 1-18, 2006a.

Conrad, B.: Out of the "memory hole": Alternative narratives of the Eritrean revolution in the diaspora, Afr. Spectr., 41, 249-271, 2006b.

Conrad, B.: "We are the Prisoners of our Dreams:" Long-distance Nationalism and the Eritrean Diaspora in Germany, Ph.D. thesis, Universität Hamburg, Germany, 2010.

Conradson, D. and Mckay, D.: Translocal Subjectivities: Mobility, Connection, Emotion, Mobilities, 2, 167-174, doi:10.1080/17450100701381524, 2007.

Ellner, S.: Landsleute sollen Eritreer integrieren helfen, http://www. nzz.ch/zuerich/landsleute-sollen-eritreer-integrieren-helfen-1. 18312040, (last access: 10 November 2016), 2014.

Etzold, B.: Migration, Informal Labour and (Trans) Local Productions of Urban Space - The Case of Dhaka's Street Food Vendors, Popul Space Place, 22, 171-184, doi:10.1002/psp.1893, 2014.

Eyer, P. and Schweizer, R.: Die somalische und die eritreische Diaspora in der Schweiz, Federal Office for Migration, Bern-Wabern, 2010.

Glatthard, F.: "Überwachung" und "Angst" im Exil?: Die eritreische Diaspora in der Schweiz, M.S. thesis, Universität Bern, Switzerland, 2012.

Greiner, C. and Sakdapolrak, P.: Translocality: Concepts, Applications and Emerging Research Perspectives, Geogr. Compass, 5, 373-384, doi:10.1111/gec3.12048, 2013.

Hall, S.: Cultural Identity and Diaspora, in: Identity: Community, Culture, Difference, edited by: Rutherford, J., Lawrence \& Wishart, London, 233-246, 1990.

Hepner, T. R.: Transnational governance and the centralization of state power in Eritrea and exile, Ethnic. Racial Stud., 31, 476502, doi:10.1080/01419870701491986, 2008.
Hepner, T. R.: Seeking Asylum in a Transnational Social Field: New Refugees and Struggles for Autonomy and Human Rights, in: Biopolitics, Militarism, and Development: Eritrea in the TwentyFirst Century, edited by: O'Kane, D. and Hepner, T. R., Berghahn Books, New York, 115-133, 2009a.

Hepner, T. R.: Soldiers, Martyrs, Traitors, and Exiles: Political Conflict in Eritrea and the Diaspora, University of Pennsylvania Press, Philadelphia, 2009b.

Hepner, T. R.: Generation nationalism and generation asylum: Eritrean migrants, the global diaspora, and the transnational nationstate, Diaspora, 18, 184-207, doi:10.1353/dsp.2015.0004, 2015 [2009].

Hepner, T. R. and O'Kane, D.: Introduction: Biopolitics, Militarism, and Development in Contemporary Eritrea, in: Biopolitics, Militarism, and Development: Eritrea in the Twenty-First Century, edited by: O'Kane, D. and Hepner, T. R., Berghahn Books, New York, ix-xxxvii, 2009.

Howard, J. A.: Social Psychology of Identities, Annu. Rev. Sociol., 26, 367-393, doi:10.1146/annurev.soc.26.1.367, 2000.

Human Rights Watch: Service for Life: State Repression and Indefinite Conscription in Eritrea, Human Rights Watch, New York, 2009.

Jiménez, T. R.: Mexican Immigrant Replenishment and the Continuing Significance of Ethnicity and Race, Am. J. Sociol., 113, 1527-1567, doi:10.1086/587151, 2008.

Kibreab, G.: The national service/Warsai-Yikealo Development Campaign and forced migration in post-independence Eritrea, J. East Afr. Stud., 7, 1-20, doi:10.1080/17531055.2013.843965, 2013.

Lohnert, B. and Steinbrink, M.: Rural and Urban Livelihoods: a Translocal Perspective in a South African Context, S. Afr. Geogr. J., 87, 95-103, doi:10.1080/03736245.2005.9713832, 2005.

Main, K. and Sandoval, G. F.: Placemaking in a translocal receiving community: The relevance of place to identity and agency, Urban Stud., 52, 71-86, doi:10.1177/0042098014522720, 2015.

Oakes, T. and Schein, L.: Translocal China: Linkages, Identities and the Reimagining of Space, Routledge, Abingdon, 2006.

Patton, M. Q.: Qualitative Evaluation and Research Methods, Sage, Beverly Hills, Ca., 1990.

Pries, L.: Configurations of geographic and societal spaces: A sociological proposal between "methodological nationalism" and the "spaces of flows", Global Netw., 5, 167-190, doi:10.1111/j.1471-0374.2005.00113.x, 2005.

Rumbaut, R. G.: Ages, Life Stages, and Generational Cohorts: Decomposing the Immigrant First and Second Generations in the United States, Int. Migr. Rev., 38, 1160-1205, doi:10.1111/j.1747-7379.2004.tb00232.x, 2004.

Ryan, L.: Ethnic and Racial Studies Who do you think you are? Irish nurses encountering ethnicity and constructing identity in Britain, Ethnic. Racial Stud., 30, 416-438, doi:10.1080/01419870701217498, 2007.

Scheurer, L.: Eritreer sind Flüchtlinge mit Imageproblem, http://www.tagesanzeiger.ch/schweiz/standard/ Eritreer-sind-Fluechtlinge-mit-Imageproblem/story/26376015 (last access: 10 November 2016), 2015.

Schoop, F. and Baumgartner, F.: Eritreer in der Schweiz: Gespaltene Gemeinschaft, http://www.nzz.ch/zuerich/ gespaltene-gemeinschaft-1.18093873 (last access: 10 January 2016), 2013. 
Schweizer Radio und Fernsehen: Asylbewerber aus Eritrea: Schutzgeld-Erpressung, http://www.srf.ch/play/tv/10vor10/ video/asylbewerber-aus-eritrea-schutzgeld-erpressung?id= e4076043-637b-47cf-9cf6-5b1e8494317e (last access: 10 November 2016), 2012.

Schweizerische Asylrekurskommission: Auszug aus dem Urteil der ARK vom 20. Dezember 2005 i.S. L.H., Eritrea, EMARK - JICRA - GICRA 2006/3, http://www.ark-cra.ch/emark/2006/03. htm (last access: 10 November 2016), 2006.

Serafini, S.: Die Angreifer von Eritreer-Fest sind selber aus Eritrea, http://www.limmattalerzeitung.ch/limmattal/region-limmattal/ die-angreifer-von-eritreer-fest-sind-selber-aus-eritrea- 126671997 (last access: 10 November 2016), 2013.

Smith, M. P.: Translocality: A Critical Reflection, in: Translocal Geographies: Spaces, Places, Connestion, edited by: Brickell, K. and Datta, A., Ashgate Publishing, Farnham, 181-189, 2001.

State Secretariat for Migration: Asylgesuche nach Nationen (1986 bis 2016), https://www.sem.admin.ch/sem/de/home/ publiservice/statistik/asylstatistik/uebersichten.html, last access: 10 November 2016.

Swiss Federal Statistical Office: Ausländische Wohnbevölkerung: Übersicht, http://www.bfs.admin.ch/bfs/portal/de/index/themen/ 01/07/blank/data/01.html, last access: 19 April 2016.

Tecle, S.: The Paradoxes of State-Led Transnationalism: Capturing Continuity, Change and Rupture in the Eritrean Transnational Social Field, M.S. thesis, York University Toronto, Canada, 2012.

Tecle, S. and Goldring, L.: From "remittance" to "tax": the shifting meanings and strategies of capture of the Eritrean transnational party-state, Afr. Black Diaspora: Internat J., 6, 189-207, doi:10.1080/17528631.2013.793137, 2013.
United Nations High Commissioner for Refugees: Asylum Levels and Trends in Industrialized Countries: Statistical overview of asylum applications lodged in Europe and selected non-European countries, http://www.unhcr.org/statistics/unhcrstats/4e9beaa19/asylumlevels-trends-industrialized-countries-2011-statisticaloverview.html (last access: 10 November 2016), 2012.

Valentine, G.: Living with difference: reflections on geographies of encounter, Prog. Hum. Geogr., 32, 323-337, doi:10.1177/0309133308089372, 2008.

Valentine, G. and Sadgrove, J.: Biographical Narratives of Encounter: The Significance of Mobility and Emplacement in Shaping Attitudes towards Difference, Urban. Stud., 51, 1979-1994, doi:10.1177/0042098013504142, 2014.

Verne, J.: Living Translocality: Space, Culture and Economy in Contemporary Swahili Trade, Franz Steiner Verlag, Stuttgart, 2012.

Vertovec, S.: Transnationalism and identity, J. Ethn. Migr. Stud., 27, 573-582, 2001.

von Nolting, N.: Gemeinschaft im Exil: Eritreische Flüchtlinge in Frankfurt am Main, M.S. thesis, Johannes Gutenberg Universität Mainz, Germany, 2002.

Yuval-Davis, N.: Theorizing identity: beyond the "us" and "them" dichotomy, Patterns Prejudice, 44, 261-280, 2010.

Zerat, S.: Identity retention and sense of belonging: an examination of second generation Eritrean youth in Toronto, M.S. thesis, Ryerson University, Toronto, Canada, 2009. 